\title{
ANALISA AKURASI PERMODELAN SUPERVISED DAN UNSUPERVISED LEARNING MENGGUNAKAN DATA MINING
}

\author{
Warnia Nengsih \\ Sistem Informasi, Politeknik Caltex Riau \\ J1 Umban Sari No 1 Rumbai Pekanbaru 28265 \\ E-mail : warnia@pcr.ac.id
}

\begin{abstract}
ABSTRAK
Data Mining merupakan salah satu proses yang menggunakan teknik statistik, matematika, kecerdasan buatan, machine learning untuk mengekstraksi dan mengidentifikasi informasi yang bermanfaat dan pengetahuan yang terkait dari berbagai database besar. Data mining memiliki dua jenis pembelajaran diantaranya supervised learning dan unsupervised learning. Tentunya setiap pembelajaran memiliki teknik dan algoritma tersendiri. Penelitian ini bertujuan untuk melakukan permodelan dari setiap learning dengan mengukur akurasi dari kedua jenis learning tersebut menggunakan beberapa metode pengujian. Sementara untuk rancang sistem menggunakan bahasa pemograman matlab. Belum adanya pengukuran akurasi dari kedua learning menjadi hal yang melatarbelakangi penelitian ini. Dari hasil pengujian akurasi menggunakan confusion matrix dan lift ratio diperoleh hasil bahwa perbandingan rata-rata akurasi untuk supervised learning adalah $82,33 \%$ dan unsupervised learning sebesar 78\% dengan selisih nilai akurasi sebesar 4,33\%. Nilai akurasi dipengaruhi oleh jumlah serta keberagaman dimensi data. Jadi dengan kasus dan jumlah serta dimensi yang berbeda akan menghasilkan nilai akurasi yang beragam pula.
\end{abstract}

Kata Kunci: Supervised Learning, Unsupervised Learning, Akurasi, Data Mining

\section{PENDAHULUAN}

Data Mining merupakan bidang ilmu yang menyatukan teknik pembelajaran, pengenalan pola, statistik, database, serta visualisasi untuk mengatasi masalah ekstraksi informasi dari basis data yang besar. Terdapat dua jenis learning pada data mining yaitu supervised learning dan unsupervised learning (Lumbantoruan, 2015). Setiap learning memiliki metode dan algoritma masing masing. Metode yang termasuk ke dalam Supervised learning diantaranya regression, classification, predictive, summarization. Seme ntara itu unsupervised learning terdiri dari metode clustering, association, knowledge discovery dan sebagainya (Mabrur, 2012).

Belum adanya pengukuran untuk mengetahui keakuratan dari salah satu permodelan pada saat menggunakan teknik tertentu untuk permasalahan dengan studi kasus yang berbeda menjadi hal yang melatarbelakangi penelitian ini. Rumusan permasalahan dapat diuraikan sebagai berikut: Bagaimana memecahkan permasalahan pada studi kasus yang berbeda dengan menggunakan teknik data mining yang ada, Bagaimana mengukur akurasi dari supervised dan unsupervised learning menggunakan studi kasus dan teknik yang beragam menggunakan metode pengujian yang sudah ditentukan

Tujuan dari penelitian ini adalah untuk mengukur akurasi dari supervised dan unsupervised learning. Pengukuran akurasi menggunakan metode confusion matrix untuk supervised learning dan pengujian akurasi lift ratio untuk unsupervised learning. Adapun jumlah variabel yang digunakan disesuaikan dengan variabel sebab (x) dari data set yang digunakan. Sistem dibangun menggunakan matlab sedangkan pengujian akurasi dilakukan di luar sistem. Output yang diperoleh dari pengukuran akurasi adalah diperolehnya sebuah pengetahuan baru berupa perbandingan akurasi dari kedua kategori learning, sehingga bermanfaat untuk pengembangan penelitian selanjutnya. Beberapa review penelitian terdahulu yang terkait dengan penelitian ini adalah penelitian dengan judul "Comparison of Supervised and Unsupervised Learning Algorthms for Pattern Classification pada International Journal of Advanced Research ini Artificial Intelligence oleh Sathya Annamma. Dimana penelitian ini menunjukkan perbandingan antara supervised dan unsupervised learning serta penentuan pola klasifikasi untuk studi kasus Pendidikan Tinggi. Kemudian review penelitian selanjutnya adalah penelitian dengan judul "Comparison of Supervised and Unsupervised Learning Classifier for Travel Recommendations" oleh Zohreh Bahman Isfahani, Shiraz University Iran. Penelitian ini membandingkan tentang pengelompokkan data pariwisata menggunakan dua metode supervised dan unsupervised. Sementara penelitian yang dilakukan sekarang adalah perbandingan dua metode learning menggunakan teknik dan studi kasus yang beragam. Perbandingan review penelitian ini dapat terlihat pada tabel berikut : 
Tabel 1. Review Penelitian terdahulu

\begin{tabular}{|l|l|l|l|}
\hline Judul & Metode Learning & Scope Riset & Output \\
\hline $\begin{array}{l}\text { Comparison of Supervised and } \\
\text { for Pattern Classification }\end{array}$ & $\begin{array}{l}\text { Supervised and } \\
\text { Unsupervised } \\
\text { Learning }\end{array}$ & $\begin{array}{l}\text { Classification } \\
\text { Teknik dengan } \\
\text { permasalahan } \\
\text { pendidikan } \\
\text { tinggi }\end{array}$ & $\begin{array}{l}\text { Membandingkan metode } \\
\text { supervised dengan } \\
\text { unsupervised pada satu studi } \\
\text { kasus yang sama }\end{array}$ \\
\hline $\begin{array}{l}\text { Comparison of Supervised and } \\
\text { Tnsupervised Learning Classifier for }\end{array}$ & $\begin{array}{l}\text { Supervised and } \\
\text { Unsupervised } \\
\text { Learning }\end{array}$ & $\begin{array}{l}\text { Classification } \\
\text { Teknik dengan } \\
\text { permasalahan } \\
\text { pariwisata }\end{array}$ & $\begin{array}{l}\text { Membandingkan metode } \\
\text { supervised dengan } \\
\text { unsupervised pada satu studi } \\
\text { kasus yang sama }\end{array}$ \\
\hline $\begin{array}{l}\text { Modeling Accuracy Analysis } \\
\text { Supervised dan Unsupervised } \\
\text { Learning Using Data Mining }\end{array}$ & $\begin{array}{l}\text { Supervised and } \\
\text { Unsupervised } \\
\text { Learning }\end{array}$ & $\begin{array}{l}\text { Semua teknik } \\
\text { data mining } \\
\text { dengan kasus } \\
\text { yang beragam }\end{array}$ & $\begin{array}{l}\text { Menentukan dan } \\
\text { membandingkan akurasi dari } \\
\text { kedua permodelan } \\
\text { menggunakan teknik-teknik } \\
\text { yang ada pada data mining } \\
\text { dengan studi kasus yang } \\
\text { berbeda. }\end{array}$ \\
\hline
\end{tabular}

\section{RUANG LINGKUP}

Berikut merupakan lingkup penelitian:

1. Penelitian ini membandingkan dua permodelan yaitu supervised learning dan unsupevised learning

2. Metode yang digunakan pada supervised learning adalah Decision tree, Support Vector Machine dan Regresi Linear. Sementara metode yang digunakan untuk untuk unsupervised learning adalah k-means, single linkage dan apriori

3. Studi kasus yang digunakan untuk setiap permodelan berbeda

\section{BAHAN DAN METODE}

Disajikan kajian teori dan metodologi dalam penelitian ini

\subsection{Analisis system}

Permasalahan prediksi, forecasting, clustering, deteksi anomali dapat menggunakan teknik data mining yang ada. Setiap teknik data mining merupakan turunan dari beberapa permodelan supervised dan unsupervised. (Prasetyo, 2014) Setiap permasalahan yang ada akan diselesaikan dengan menggunakan permodelan yang sudah dibuat dengan menggunakan teknik yang tepat untuk mendapatkan knowledge atau pengetahuan. Namun perlu adanya pengukuran akurasi dari setiap model pembelajaran yang digunakan, sehingga dapat disimpulkan persentase akurasi dari setiap permasalahan dengan teknik yang digunakan pada setiap permodelan.

Secara konsep, jika akurasi tinggi dan nilai kesalahan rendah maka menunjukkan hasil yang baik terhadap keakuratan permodelan yang dihasilkan. Namun sebaliknya jika nilai akurasi rendah dan dan nilai kesalahan tinggi maka tentunya teknik yang dipilih belum tepat untuk menyelesaikan permasalahan tersebut.

Pengukuran akurasi dari kedua jenis learning tersebut menggunakan beberapa metode pengujian disesuaikan dengan metode learning yang digunakan.
Dataset diambil dari studi kasus yang berbeda disesuaikan dengan permodelan yang digunakan.

\subsection{Implementasi Sistem}

Selanjutnya dilakukan permodelan sistem menggunakan matlab sesuai dengan metode pembelajaran yang digunakan.

\subsection{Pengujian}

Pengujian digunakan untuk mengukur akurasi dari sebuah kasus dengan metode yang digunakan. Adapun pengujian yang digunakan adalah confusion matrix dan lift ratio untuk masing - masing learning.

\subsection{Confusion Matrix}

Confusion matrix merupakan salah satu metode yang dapat digunakan untuk mengukur kinerja suatu metode klasifikasi. Pada dasarnya confusion matrix mengandung informasi yang membandingkan hasil klasifikaasi yang dilakukan oleh sistem dengan hasil klasifikasi yang seharusnya (Afrisawati, 2002)

\subsection{Lift Ratio}

Lift Ratio adalah parameter penting selain support dan confidence dalam association rule. Lift Ratio mengukur seberapa penting rule yang telah terbentuk berdasarkan nilai support dan confidence.

Penelitian ini menggunakan beberapa metode pada supervised learning diantaranya regresi linear, decision tree dan Support Vector Machine. Serta metode unsupervised learning diantaranya K-Means, single linkage dan apriori. Interface sistem untuk kasus menggunakan bahasa pemograman matlab. Penelitian ini menggunakan data dengan studi kasus yang berbeda karena harus disesuaikan dengan kebutuhan metode yang digunakan. Metode pengujian menggunakan confusion matrix untuk supervised learning dan lift ratio untuk metode-metode yang terdapat pada unsupervised 
learning. Berikut gambar 1 merupakan gambaran umum dari penelitian.

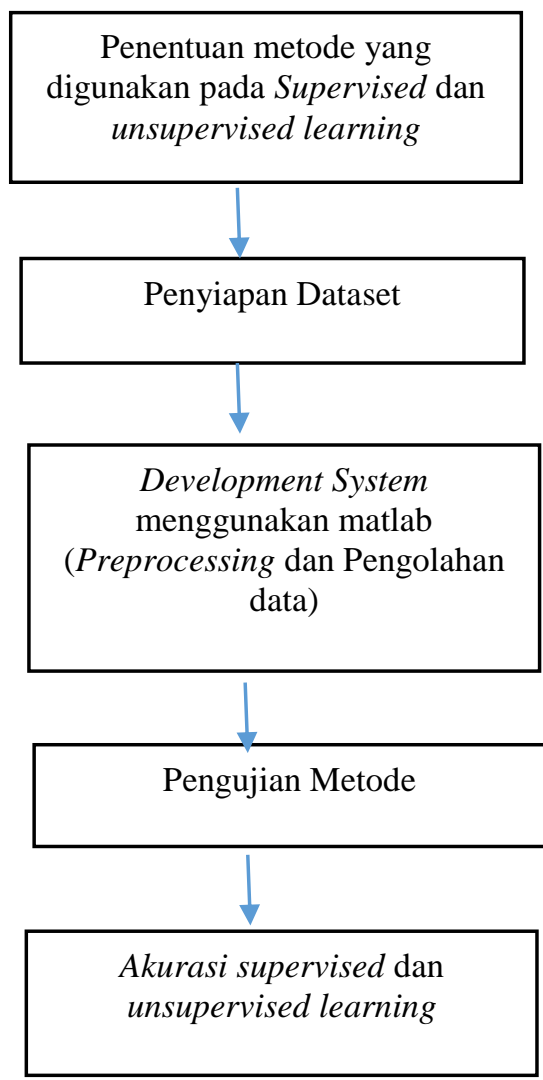

Gambar 1. metodologi penelitian

\section{PEMBAHASAN}

Disajikan hasil dan pembahasan dalam penelitian ini

\subsection{Metode $K$-Means}

K-Means merupakan salah satu algoritma clustering (al, 2016). Tujuan algoritma ini yaitu untuk membagi data menjadi beberapa kelompok. Algoritma ini menerima masukan berupa data tanpa label kelas. (F. E. M. Agustin, 2013). K-means merupakan salah satu algoritma clustering. Tujuan algoritma ini yaitu untuk membagi data menjadi beberapa kelompok. Algoritma ini menerima masukan berupa data tanpa label kelas. Hal ini berbeda dengan supervised learning yang menerima masukan berupa vektor $\left(x_{1}, y_{1}\right),\left(x_{2}, y_{2}\right), \ldots,\left(x_{i}, y_{i}\right)$, di mana $x_{i}$ merupakan data dari suatu data pelatihan dan $y_{i}$ merupakan label kelas untuk $x_{i}$ (K. Rajalakshmi). Berikut merupakan dataset yang digunakan.

\begin{tabular}{|r|r|r|}
\hline 5.34 & 211.4 & 39.588 \\
\hline 1.16 & 40.8 & 35.1724 \\
\hline 6.5 & 252.2 & 38.8 \\
\hline 9.66 & 221.47 & 22.9265 \\
\hline 9.66 & 221.47 & 22.9265 \\
\hline 9.66 & 221.47 & 22.9265 \\
\hline 50 & 200 & 20 \\
\hline 60 & 100 & 19 \\
\hline 70 & 150 & 18 \\
\hline 30 & 130 & 17 \\
\hline 40 & 140 & 16 \\
\hline 50 & 160 & 14 \\
\hline 40 & 135.33 & 3.38325 \\
\hline 110 & 24 & 0.21818 \\
\hline 150 & 159.33 & 1.0622 \\
\hline 13 & 78 & 15 \\
\hline 12 & 88 & 14 \\
\hline 28.74 & 3278.61 & 114.078 \\
\hline 22.49 & 3090.11 & 137.399 \\
\hline 6.25 & 188.5 & 30.16 \\
\hline 6.25 & 188.5 & 30.16 \\
\hline 6.25 & 188.5 & 30.16 \\
\hline 6.25 & 188.5 & 30.16 \\
\hline 6.25 & 188.5 & 30.16 \\
\hline 6.25 & 188.5 & 30.16 \\
\hline 6.25 & 188.5 & 30.16 \\
\hline 6.25 & 188.5 & 30.16 \\
\hline 6.48 & 1793.09 & 276.711 \\
\hline 54.52 & 1576 & 28.9068 \\
\hline & & \\
\hline
\end{tabular}

\section{Gambar 2. Data set menggunakan K-Means}

Dari data ini terdapat 3 variabel sebab (X), yaitu Produktivitas, Luas Lahan, Produksi. Output dataset menggunakan 2 cluster

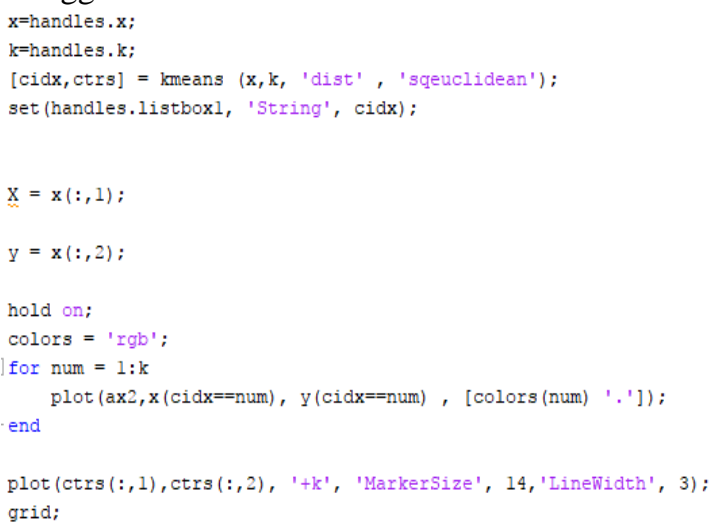

Berikut merupakan hasil cluster dari dataset yang diolah. 


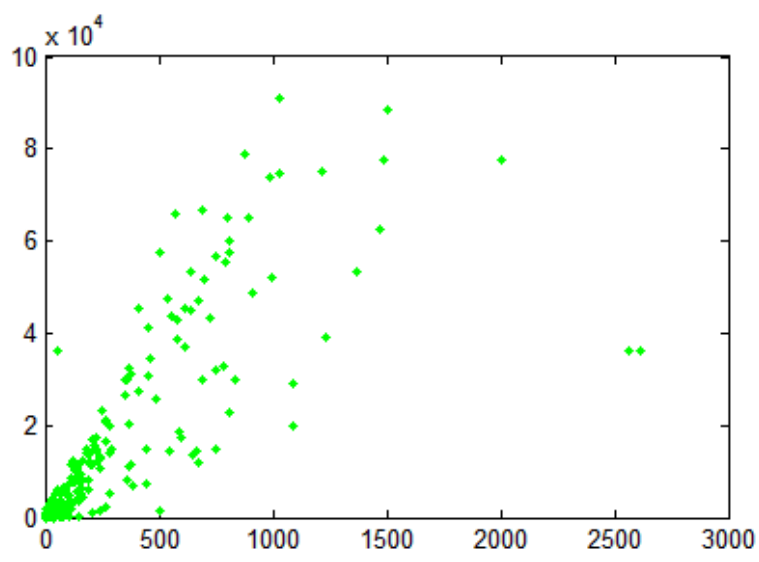

Gambar 3. Hasil pengclusteran menggunakan KMeans

\subsection{Metode Single linkage}

Single linkage merupakan metode yang terdapat pada kategori clustering hirarki yang jumlah clusternya diperoleh setelah pengolahan data dilakukan. Berikut ini dataset yang digunakan.

\begin{tabular}{|c|c|c|}
\hline 100 & 130 & 110 \\
\hline 150 & 125 & 100 \\
\hline 120 & 120 & 100 \\
\hline 110 & 120 & 100 \\
\hline 130 & 110 & 100 \\
\hline 100 & 110 & 110 \\
\hline 100 & 120 & 175 \\
\hline 100 & 145 & 110 \\
\hline 100 & 150 & 175 \\
\hline 100 & 160 & 150 \\
\hline 150 & 160 & 150 \\
\hline 100 & 160 & 150 \\
\hline 150 & 145 & 175 \\
\hline 150 & 150 & 175 \\
\hline 150 & 160 & 150 \\
\hline 130 & 125 & 175 \\
\hline 100 & 160 & 175 \\
\hline 100 & 150 & 175 \\
\hline 100 & 150 & 110 \\
\hline 140 & 125 & 150 \\
\hline 120 & 160 & 150 \\
\hline 120 & 150 & 175 \\
\hline 100 & 150 & 175 \\
\hline
\end{tabular}

Gambar 4. Data set menggunakan single linkage

Dataset yang digunakan untuk mengetahui cluster pegawai tidak memenuhi dan memenuhi dengan menggunakan 3 kriteria yaitu nilai TWK (Tes Wawancara Kebangsaan),TIU (Tes Inteligent Umum) dan TKP (Tes Karakteristik Kepribadian).

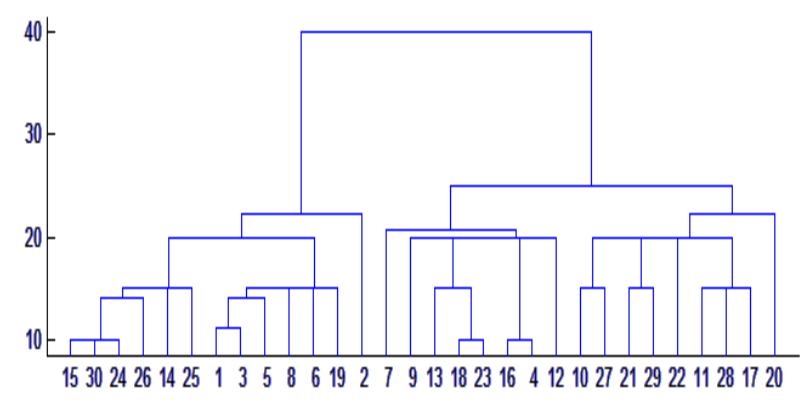

Gambar 5. Hasil pengclusteran menggunakan Single Linkage

\subsection{Metode Apriori}

Berikut merupakan dataset yang digunakan pada apriori

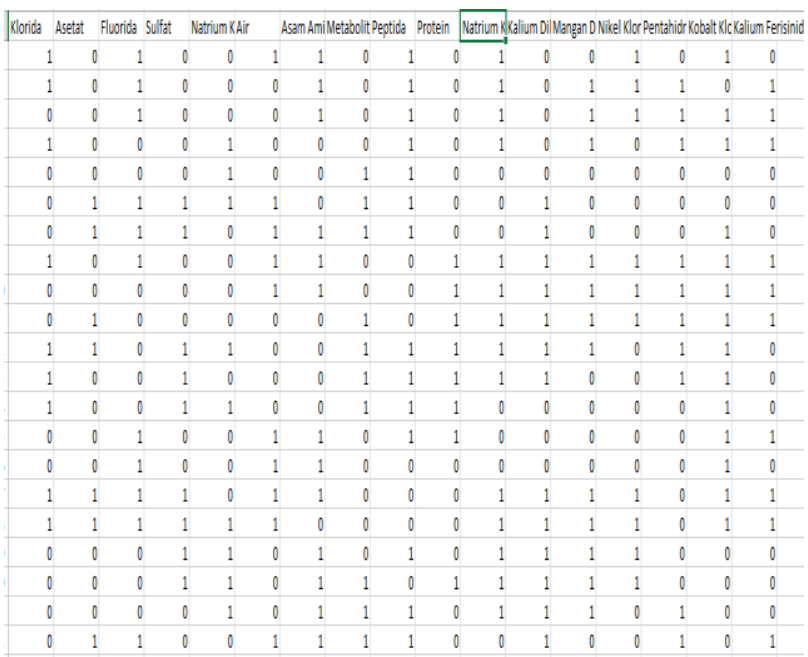

Gambar 6. Dataset menggunakan apriori

Algoritma apriori adalah suatu metode untuk mencari pola hubungan antar satu atau lebih item dalam suatu dataset (K. Tampubolon, 2013).Pada metode ini tentukan nilai minimum support dan minimum confidence yang digunakan untuk mengetahui berapa nilai keterkaitan antara item.Gambar 7 menunjukkan rule dari nilai keterkaitan yang diperoleh 


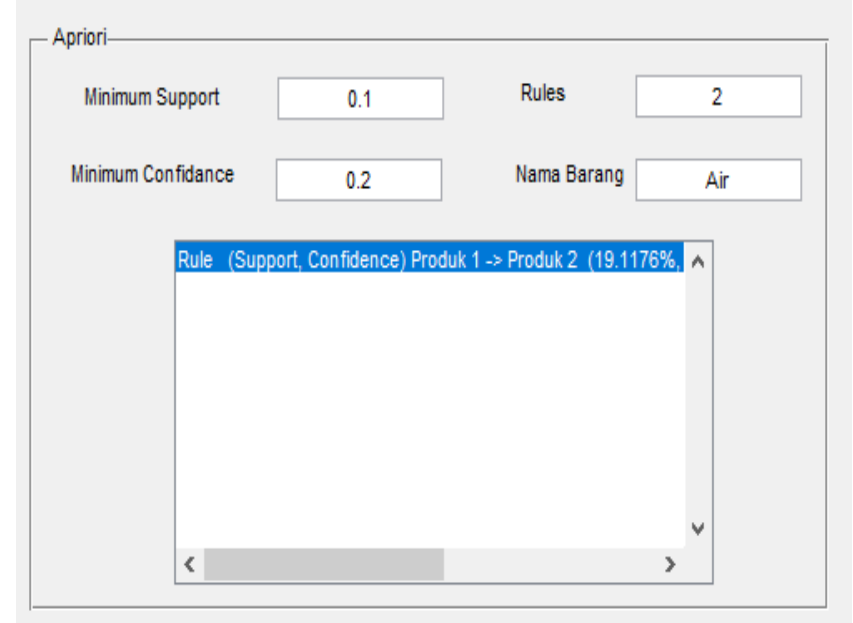

Gambar 7. Hasil asosiasi menggunakan matlab

\subsection{Metode Decision Tree}

Decision tree merupakan salah satu metode teknik klasifikas dimana kelas data sudah diketahui sebelumnya.

\begin{tabular}{|c|c|c|}
\hline 6 & 5 & 3 \\
\hline 1 & 6 & 4 \\
\hline 4 & 7 & 4 \\
\hline 5 & 7 & 4 \\
\hline 3 & 8 & 4 \\
\hline 6 & 8 & 3 \\
\hline 6 & 7 & 1 \\
\hline 6 & 4 & 3 \\
\hline 6 & 3 & 1 \\
\hline 6 & 2 & 2 \\
\hline 1 & 2 & 2 \\
\hline 6 & 2 & 2 \\
\hline 1 & 4 & 1 \\
\hline 1 & 3 & 1 \\
\hline 1 & 2 & 2 \\
\hline 3 & 6 & 1 \\
\hline 6 & 2 & 1 \\
\hline 6 & 3 & 1 \\
\hline 6 & 3 & 3 \\
\hline 5 & 6 & 2 \\
\hline 3 & 2 & 2 \\
\hline 3 & 3 & 1 \\
\hline 1 & 3 & 1 \\
\hline
\end{tabular}

\section{Gambar 8. Dataset mengunakan Decision Tree}

Berikut merupakan rule yang digunakan dari hasil pengolahan dataset.

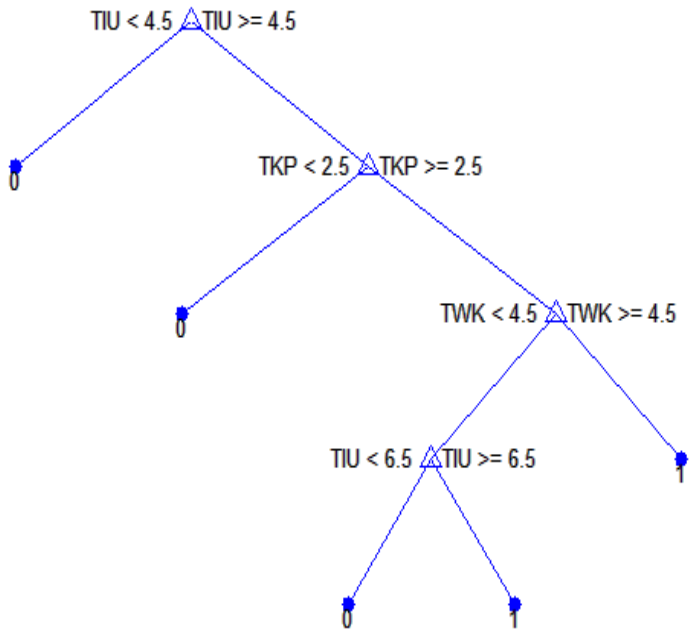

Gambar 9. hasil pohon keputusan

Dari pohon keputusan tersebut didapat informasi bahwa jika TIU (Tes Inteligent Umum) kecil dari 4.5 maka hasilnya memenuhi. Dan jika TIU (Tes Inteligent Umum) besar dari 4.5 dan TKP besar dari 2.5 serta TWK besar dari 4.5 maka label yang diperoleh tidak memenuhi. Jika TIU besar dari 4.5 dan TKP (Tes Karakteristik Kepribadian) kecil dari 2.5 maka memenuhi. Selanjutnya jika TIU besar dari 4.5,TKP besar dari 2.5 dan TWK kecil dari 4.5 serta TIU $<6.5$ maka label yang digunakan memenuhi. Jika TIU besar dari 4.5,TKP besar dari 2.5 dan TWK kecil dari 4.5 serta TIU> 6.5 maka label yang digunakan tidak memenuhi

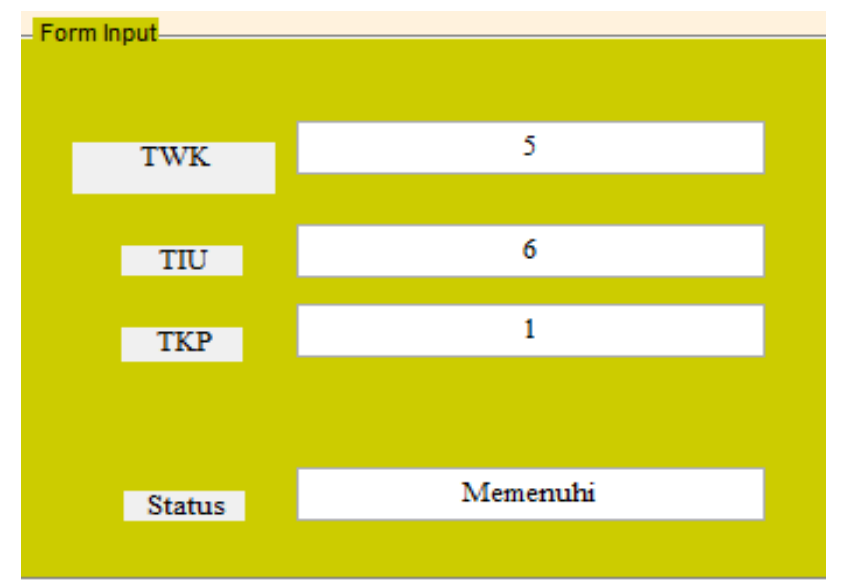

Gambar 10. Hasil prediksi menggunakan Decision Tree

\subsection{Metode Support Vector Machine(SVM)}

Teknik SVM digunakan untuk menemukan fungsi pemisah(klasifier) yang optimal yang bisa memisahkan dua set data dari dua kelas yang berbeda (Kurniawan Defri, 2013). Berikut merupakan hasil interface yang digunakan untuk metode SVM. Studi kasus yang digunakan adalah untuk melakukan prediksi jenis pinjaman untuk nasabah. 


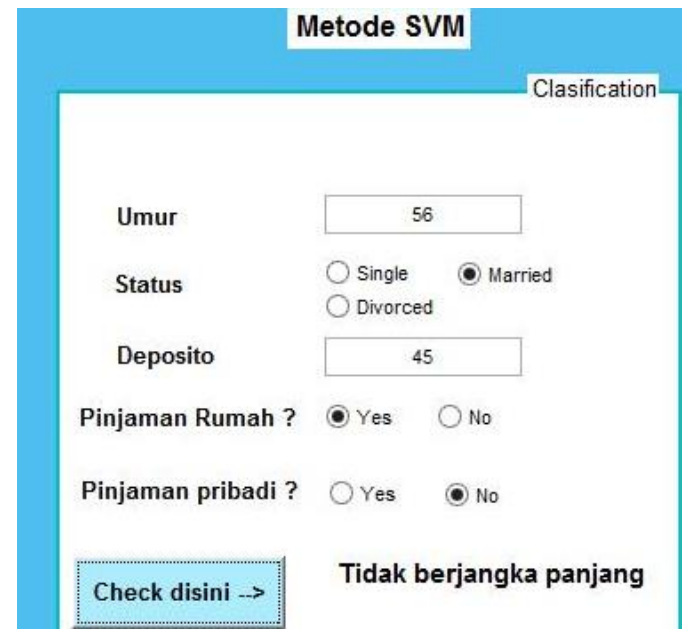

Gambar 11. Hasil prediksi menggunakan SVM

\subsection{Metode linear regresi}

Berikut merupakan data yang digunakan untuk regresi linear.

\begin{tabular}{|c|c|c|}
\hline 5.34 & 211.4 & 39.588 \\
\hline 1.16 & 40.8 & 35.1724 \\
\hline 6.5 & 252.2 & 38.8 \\
\hline 9.66 & 221.47 & 22.9265 \\
\hline 9.66 & 221.47 & 22.9265 \\
\hline 9.66 & 221.47 & 22.9265 \\
\hline 50 & 200 & 2 \\
\hline 60 & 100 & 1 \\
\hline 70 & 150 & 1 \\
\hline 30 & 130 & 1 \\
\hline 40 & 140 & 1 \\
\hline 50 & 160 & 1 \\
\hline 40 & 135.33 & 3.38325 \\
\hline 110 & 24 & 0.2181 \\
\hline 150 & 159.33 & 1.062 \\
\hline 13 & 78 & 1 \\
\hline 12 & 88 & 1 \\
\hline 28.74 & 3278.61 & 114.078 \\
\hline 22.49 & 3090.11 & 137.399 \\
\hline 6.25 & 188.5 & 30.1 \\
\hline 6.25 & 188.5 & 30.16 \\
\hline 6.25 & 188.5 & 30.1 \\
\hline 6.25 & 188.5 & 30.10 \\
\hline 6.25 & 188.5 & 30.16 \\
\hline 6.25 & 188.5 & 30.1 \\
\hline 6.25 & 188.5 & 30.1 \\
\hline 6.25 & 188.5 & 30.16 \\
\hline 6.48 & 1793.09 & 276.71 \\
\hline 54.52 & 1576 & 28.906 \\
\hline
\end{tabular}

Gambar 12. Dataset untuk metode linear regresi
Dataset yang digunakan untuk menentukan jumlah produksi garam. Adapun variabel yang digunakan adalah luas lahan, produktivitas, produksi.

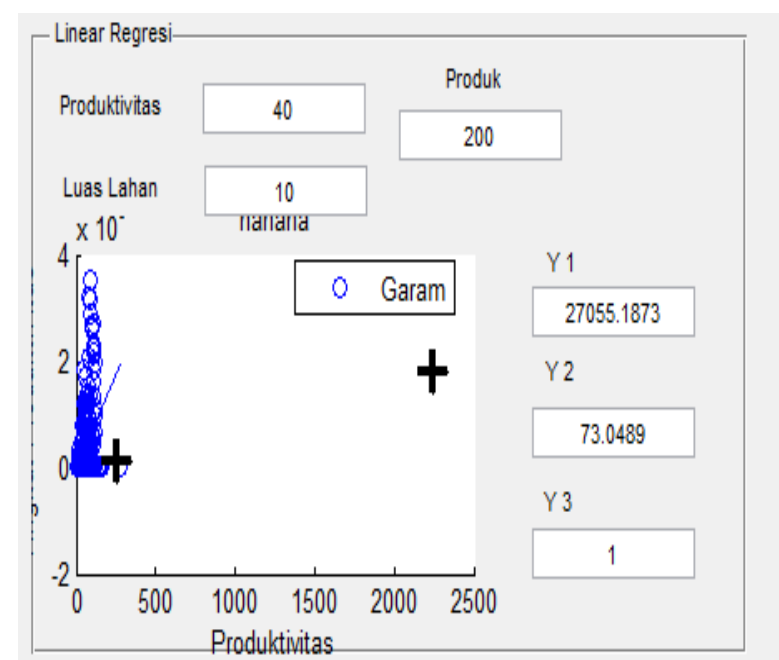

Gambar 13. Hasil dari Metode Linear Regresi

Berikut merupakan hasil pengujian akurasi unuk setiap learning:

Tabel 2 Hasil akurasi metode supervised learning

\begin{tabular}{|l|l|l|}
\hline No & Metode Supervised Learning & $\begin{array}{l}\text { Nilai } \\
\text { Akurasi }\end{array}$ \\
\hline 1 & Regresi Linear & $80 \%$ \\
\hline 2 & Decision Tree & $87 \%$ \\
\hline 3 & Support Vector Machine & $80 \%$ \\
\hline \multicolumn{2}{|l|}{ Rata-rata akurasi } & $82,33 \%$ \\
\hline
\end{tabular}

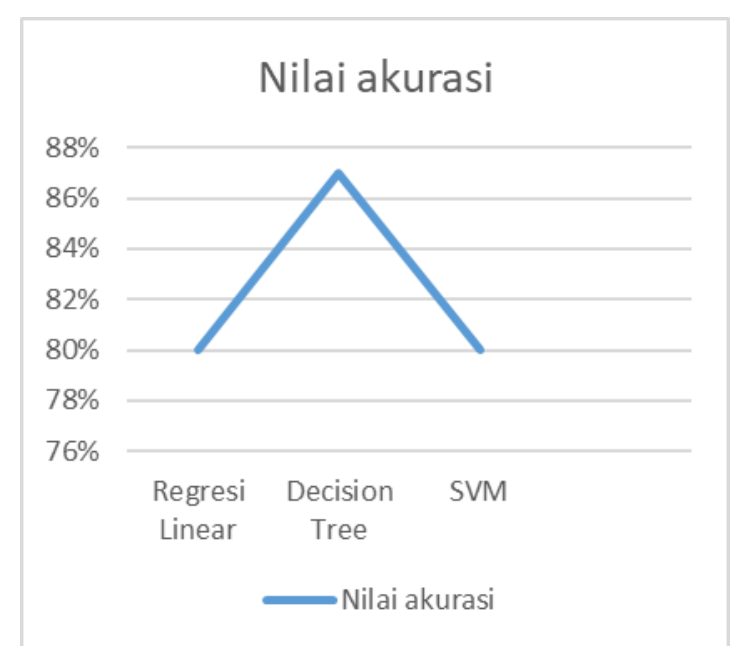

Gambar 14. visualisasi akurasi supervised learning

Untuk hasil akurasi metode unsupervised ditunjukkan pada tabel 2 . 
Tabel 3. Hasil akurasi metode unsupervised learning

\begin{tabular}{|l|l|l|}
\hline No & Nnsupervised Learning & Nilai Akurasi \\
\hline 1 & K-means & $76 \%$ \\
\hline 2 & Hierarichal clustering & $78 \%$ \\
\hline 3 & Apriori & $80 \%$ \\
\hline \multicolumn{2}{|l|}{ Rata-rata akurasi } & $78 \%$ \\
\hline
\end{tabular}

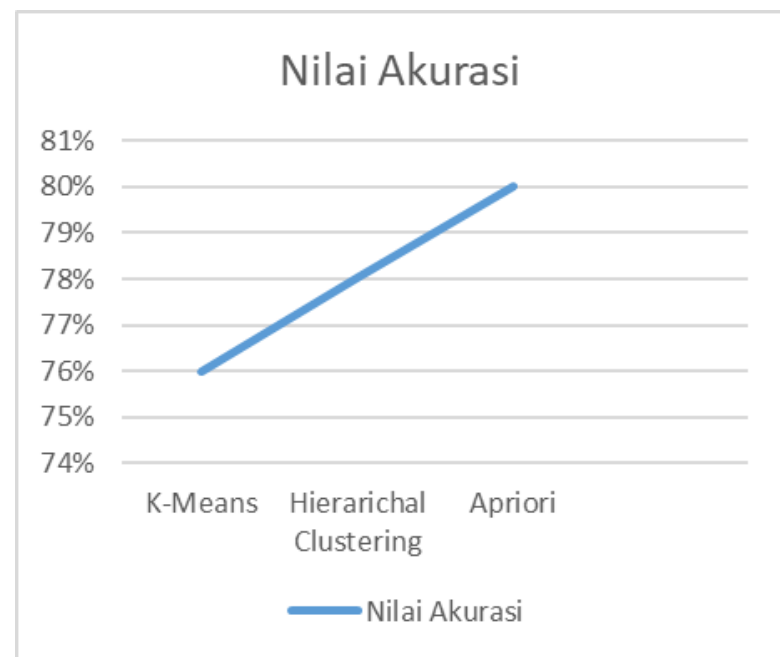

Gambar 15. visualisasi akurasi unsupervised learning

Tabel 4. Perbandingan rata-rata akurasi

\begin{tabular}{|c|c|}
\hline $\begin{array}{c}\text { Supervised } \\
\text { Learning(akurasi) }\end{array}$ & $\begin{array}{c}\text { Unsupervised } \\
\text { Learning(akurasi) }\end{array}$ \\
\hline $82,33 \%$ & $78 \%$ \\
\hline
\end{tabular}

Berikut merupakan rata-rata akurasi untuk supervised learning 82,33\% dan unsupervised learning sebesar $78 \%$ dengan selisih nilai akurasi sebesar 4,33\%. Dimana nilai akurasi dipengaruhi oleh jumlah serta keberagaman dimensi data. Jadi dengan kasus dan jumlah serta dimensi yang berbeda akan menghasilkan nilai akurasi yang beragam pula.

\section{KESIMPULAN}

Penelitian ini menggunakan beberapa metode pada supervised learning diantaranya regresi linear, decision tree dan Support Vector Machine. Serta metode unsupervised learning diantaranya K-Means, single linkage dan apriori. Interface sistem untuk kasus menggunakan bahasa pemograman matlab. Penelitian ini menggunakan data dengan studi kasus yang berbeda karena harus disesuaikan dengan kebutuhan metode yang digunakan. Dari hasil pengujian akurasi menggunakan confusion matrix dan lift ratio diperoleh hasil bahwa Perbandingan rata-rata akurasi untuk supervised learning adalah $82,33 \%$ dan unsupervised learning sebesar $78 \%$ dengan selisih nilai akurasi sebesar 4,33\%. Nilai akurasi dipengaruhi oleh jumlah serta keberagaman dimensi data. Jadi dengan kasus dan jumlah serta dimensi yang berbeda akan menghasilkan nilai akurasi yang beragam
pula.Metode supervised dan unsupervised learning yang digunakan harus lengkap sehingga dapat mewakili semua metode pada masing-masing learning yang digunakan

\section{SARAN}

Saran untuk penelitian berikutnya menggunakan dataset yang sama untuk setiap permodelan, sehingga dapat dilihat perbandingan akurasinya.

\section{DAFTAR PUSTAKA}

Afrisawati. 2002. Implementasi Data Mining Pemilihan Pelanggan Potensial menggunakan Algoritma K-Means, Pelita Inform. Budi Darma, vol. $V$, no. 12110955, (2013):pp. 157-162.

E. Prasetyo.2014. Data Mining: Konsep dan Aplikasi menggunakan Matlab, 1 ed. Yogyakarta: Andi Offset.

F. E. M. Agustin, A. Fitria, and A. H. S. 2013." Implementasi Algoritma K-Means Untuk Menentukan Kelompok Pengayaan Materi Mata Pelajaran Ujian Nasional. (Studi Kasus Smp Negeri 101 Jakarta), vol. 8:pp. 73-78.

G.Abdillah et al.2016. Penerapan Data Mining Pemakaian Air Pelanggan Untuk Menentukan Klasifikasi Potensi Pemakaian Air Pelanggan Baru Di PDAM Tirta Raharja Menggunakan Algoritma K-Means,:pp. 18-19.

Kurniawan Defri, Catur Suprianto. 2013. Optimasi Algoritma Support Vector Machine untuk penilaian Risiko Kredit, Universitas Dian Nuswantoro.

K. Tampubolon, H. Saragih, B. Reza, K. Epicentrum, .2013. "Implementasi Data Mining Algoritma Apriori Pada Sistem Persediaan Alat-Alat Kesehatan," Inf. dan Teknol. Ilm.,: pp. 93-106.

K. Rajalakshmi, S. S. Dhenakaran, and N. Roobini, "Comparative Analysis of K-Means Algorithm in Disease Prediction," Int. J. Sci. Eng. Technol. Res., vol. 4, no. 7, pp. 2697-2699

Lumbantoruan, Rutman dan Posma Sariguna Johnson Kennedy.2015. "Analisis Data Mining Dan Warehousing". Jurnal Ilmiah Buletin Ekonomi, Volume 19 no.1.

L. R. Angga Ginanjar Mabrur.2012. "Penerapan Data Mining Untuk Memprediksi Kriteria Nasabah Kredit," J. Komput. dan Inform., vol. 1, no. 1:pp. $53-57$ 